Ekonomia - Wroclaw Economic Review 26/1 (2020)

Acta Universitatis Wratislaviensis

No 3991

https://doi.org/10.19195/2658-1310.26.1.6

Gabriela Dubiec

ORCID: 0000-0001-9623-1724

Uniwersytet Wrocławski

gabriela.dubiec@wp.pl

\title{
Wykorzystanie wybranych metod wielowymiarowej analizy porównawczej do oceny poziomu zjawiska przestępczości w powiatach Polski w 2012 roku
}

Artykuł nadesłany: 20.04.2020; artykuł zaakceptowany: 30.04.2020

Kody klasyfikacji JEL: C1, C38, J28, K14, K42, R1

Keywords: crime, multidimensional analysis, crime determinants, taxonomy, Ward's method, synthetic measure of development, pattern and anti-pattern method

\section{Abstract}

The use of selected methods of multidimensional comparative analysis to assess the level of crime in Polish counties in 2012

The article attempts to identify particularly vulnerable counties which are prone to the phenomenon of crime and to create crime maps using multi-dimensional comparative analysis (MCA). As a tool for comparing Polish counties in terms of crime and identifying factors determining it, the article uses two MCA methods, i.e. the pattern and anti-pattern method, and the Ward method as an example of a hierarchical grouping method. Therefore, a synthetic measure of crime was determined, which replaces the set of many features of the examined objects (in this case they are variables characterising crime) into one aggregated normalised variable. This approach not only enables the assessment of counties using one quantity, but also allows them to be ordered in terms of the phenomenon under consideration.

\section{Wstęp}

Zjawisko przestępczości jako złożone i niepożądane wywiera wpływ na każdą dziedzinę życia jednostek (Grzeszyk, Sławik, 1985, 3). Jest zjawiskiem społecz- 
nym będącym zagrożeniem dla porządku publicznego i wyraża się go stosunkiem osób, jakie popełniły czyn zabroniony, do ogółu ludności. Określenie przyczyn i czynników wpływających na siłę, charakter oraz natężenie i intensywność czynów zabronionych jest fundamentalne z punktu widzenia zapobiegania oraz podejmowania działań prewencyjnych w sferze przestępczości. Tymczasem pomiar wspomnianego zjawiska jest problemowy. Nie każde przestępstwo jest bowiem rejestrowane, co tworzy tak zwaną ciemną liczbę przestępstw. Badanie determinantów przestępczości jest wciąż aktualne i ważne ze względu na wiele prac traktujących na ten temat i próby odpowiedzi na pytanie o uwarunkowania przestępczości.

Celem artykułu jest ocena struktury przestrzennego zróżnicowania przestępczości w Polsce w 2012 roku w poszczególnych powiatach, a także analiza najczęściej wymienianych czynników mających na nią wpływ. Praca ma za zadanie zaprezentowanie wykorzystania metod wielowymiarowej analizy porównawczej w sklasyfikowaniu powiatów ze względu na zjawisko przestępczości. W pracy zastosowano dwie spośród metod wielowymiarowych, to jest metodę rozwoju oraz metodę Warda. Metody te zostały wybrane ze względu na dostępność narzędzi analiz, a także liczbę badanych jednostek i cech je charakteryzujących. Aglomeracyjna metoda Warda wzbogaciła efekt uporządkowanych liniowo obiektów, grupując powiaty ze względu na podobieństwo w zakresie przestępczości, co pozwala ocenić, czy powiaty o największym lub najmniejszym współczynniku przestępczości mieszczą się w tej samej grupie. W pracy wykorzystano programy Gretl, MS Excel, R oraz Statistica.

\section{Przegląd literatury z zakresu badania determinant przestępczości}

Uwarunkowaniami przestępczości zajmowało się wielu badaczy. Za twórcę nauki kryminologii na początku XIX wieku uważa się Cesarego Lombroso — włoskiego lekarza. Należy również wskazać na powstałą w 1925 książkę napisaną przez dwóch socjologów miasta Roberta E. Parke i Ernesta W. Burgessa The City, która jest uważana za jedną z najwybitniejszych dokonań XX wieku w zakresie kryminologii miasta. Brunon Hołyst — polski kryminolog — pisał dość obszernie o problemie uwarunkowań przestępczości (Hołyst, 2016). Studiami w zakresie determinantów przestępczości zajmowała się Anna Kiersztyn, której praca $C z y$ bieda czyni złodzieja. Związek między bezrobociem a przestępczości (2008) jest studium w całości poświęconym zależnościom między ekonomiczną sytuacją ludności a współczynnikami przestępstw. Przestrzenne zróżnicowanie przestępczości w skali krajowej i regionalnej w Polsce było analizowane w nielicznych pracach (należy przywołać tu zwłaszcza pracę Bartosza Czarneckiego Przestrzenne aspekty przestępczości. Metoda identyfikacji czynników zagrożeń w przestrzeni 
miejskiej z 2011 roku). Ukazujący się od 1994 roku Atlas przestępczości w Polsce (Siemaszko, Marczewski, Gruszczyńska, 2015) zawiera materiały przedstawiające zróżnicowanie przestrzenne przestępczości według województw. Badaczką zajmującą się genezą przestępczości jest Kinga Kądziołka, która omawianej tematyce poświęciła wiele artykułów, na przykład Bezrobocie, ubóstwo i przestępczość w Polsce. Analiza zależności na poziomie województw, którego celem było zbadanie zależności miedzy bezrobociem i ubóstwem a przestępczością w Polsce na poziomie województw. Należy wskazać również publikację Janiny Błachut Problemy zwiazane z pomiarem przestępczości (2007) — poświęconą problematyce diagnozowania przestępczości. Autorka podejmuje się odpowiedzi na pytania: dlaczego i jak mierzymy przestępczość? Z jakimi problemami musi zmierzyć się badacz, a także jakie niesie to $\mathrm{z}$ sobą nieporozumienia? Niniejszy artykuł jest próbą scalenia zebranych źródeł i pogłębioną analizą zebranych materiałów, nie odnosząc się w sposób krytyczny do już wydanych opracowań jedynie uzupełnia analizy przestępczości.

\section{Zarys teorii wielowymiarowej analizy danych}

W wielowymiarowej analizie porównawczej największe zastosowanie znalazły metody taksonomiczne, w których porównywanie obejmuje porządkowanie obiektów oraz grupowanie jednostek w podzbiory wykazujące podobieństwo, a następnie wybór reprezentantów grup (Panek, Zwierzchowski, 2013, 11-13). Obiekty objęte analizą tworzą zbiorowość, a zmienną jest cecha lub własność, która daną zbiorowość będzie opisywała. Wówczas wielowymiarowe obserwacje zapisuje się w postaci macierzy (obserwacji lub macierzy danych) oznaczonej $X=\left[X_{i j}\right]$, gdzie $X_{i j}$ oznacza wartość tej zmiennej zaobserwowanej u $i-$ tego obiektu (obiekty $i=1, \ldots n$ są jednostkami przestrzennymi).

Metody taksonomiczne pozwalają na uszeregowanie obiektów zgodnie z poziomem zjawiska (Sobolewski, 2015, 159-168). Metody grupowania dzielą się między innymi na metody obiektów uporządkowanych liniowo i aglomeracyjne, natomiast metody porządkowania są dzielone na metody porządkowania liniowego i nieliniowego. Wśród metod klasyfikacyjnych wyróżniamy metody hierarchiczne (aglomeracyjne i podziału) i niehierarchiczne, a także grupowanie obiektów uporządkowanych liniowo. W pracy wykorzystano liniowe porządkowanie obiektów i jest to metoda o następujących własnościach:

— obiekt ma co najmniej jednego sąsiada, ale nie więcej niż dwóch;

— jeśli i-ty obiekt sąsiaduje z i-tym obiektem, to na odwrót zależność ta również jest spełniona;

— tylko dwa obiekty mają jednego sąsiada.

W artykule wykorzystano jedną z metod liniowego porządkowania, to jest metodę opartą na zmiennych syntetycznych - metodę wzorca i antywzorca. Me- 
toda wzorca opiera się na znormalizowanych wartościach zmiennych. Pierwszym etapem jest stworzenie obiektu wzorcowego, który charakteryzuje się ,idealnymi” cechami. Najbardziej rozpowszechnioną metodą wzorcową jest tak zwana metoda rozwoju Hellwiga. Po standaryzacji zmiennych wyznacza się obiekt, tak zwany wzorzec. W kolejnym etapie dla każdego obiektu oblicza się odległość od wzorca stanowiącego podstawę wyznaczenia miary syntetycznej przyjmującej wartości z przedziału $[0 ; 1]$. Wartości tej miary zwiększają się w miarę oddalania obiektu od wzorca.

Istotą metod aglomeracyjnych jest traktowanie każdej z badanych jednostek jako odrębnego skupienia - liczba grup będzie odpowiadała liczbie analizowanych obiektów, a proces klasyfikacji będzie polegał na łączeniu w pary tych grup. Każdą z metod można scharakteryzować, używając tak zwanej centralnej procedury aglomeracyjnej (Nowak, 1990, 80). Jedną z metod jest metoda Warda, która wyróżnia się wykorzystaniem analizy wariancji w celu oszacowania odległości między skupieniami. Zmierza ona do minimalizacji sumy kwadratów odchyleń wewnątrz skupień (Stanisz, 2007, 122). Można wskazać pewien schemat postępowania w sposobie grupowania metodą Warda, w której G oznacza kolejne skupienie, a d odległość między nimi:

1) wyznacza się macierz odległości o wymiarze n-n zawierającej odległości między skupieniami $\mathrm{G}_{1}, \ldots \mathrm{G}_{\mathrm{n}}$ :

2) w kolejnym kroku szuka się pary skupień o najmniejszej odległości. Będą to dwa obiekty, które dzieli najmniejsza odległość euklidesowa:

$$
\left[\sum_{j=1}^{m}\left(z_{i j}-z_{0 j}\right)^{2}\right]^{\frac{1}{2}} j=1,2, \ldots ; i=1,2, \ldots n
$$

gdzie:

$\mathrm{z}_{\mathrm{ij}}$ - zestandaryzowana zmienna

$m$ - liczba zmiennych diagnostycznych

3) skupienie $\mathrm{G}_{\mathrm{p}}$ oraz $\mathrm{G}_{\mathrm{q}}$ zostaje połączone w jedno o numerze $p$;

$$
\mathrm{G}_{\mathrm{p}}=\mathrm{G}_{\mathrm{p}} \cup \mathrm{G}_{\mathrm{q}}
$$

4) z macierzy zostają usunięte wiersz i kolumna o numerze $q$, w ich miejsce wstawione $\mathrm{n}=\mathrm{n}-1$.

5) wyznacza się odległości $d_{p j}=(j=1,2, \ldots, n)$ skupienia $G_{p}$ od pozostałych skupień. Wartości $\mathrm{d}_{\mathrm{pj}}$ zostają umieszczone w macierzy D w miejsce $\mathrm{p}$ - tego wiersza, a w miejsce $\mathrm{p}$ - tej kolumny elementy $\mathrm{d}_{\mathrm{jp}}$;

6) kroki 2-5 zostają powtórzone do momentu, w którym każdy z analizowanych obiektów utworzy jedno skupienie. 


\section{Metodologia badań}

Metody porządkowania liniowego zostały wybrane na podstawie studiów literatury z zakresu wielowymiarowej analizy porównawczej. Sporządzanie rankingu obiektów było przeprowadzane w następujących etapach:

1. dobór i selekcja zmiennych diagnostycznych,

2. standaryzacja zmiennych,

3. obliczenie zmiennych syntetycznych będących agregatami zmiennych diagnostycznych,

4. stworzenie rankingu porównywanych obiektów,

5. przeprowadzenie oceny wyników klasyfikacji i porównanie z innym rankingiem,

6. ocena klasyfikacji na podstawie wskaźnika zgodności klasyfikacji V-Cramera,

7. wykorzystanie metody Warda do podziału obiektów w jednorodne grupy,

8. ocena otrzymanych wyników.

Wejściowy zestaw zmiennych, determinujący poziom zjawiska przestępczości, ustalono na podstawie ich dostępności, a także kryteriów pozastatystycznych (Panek, Zwierzchowski, 2013, 18-21), to jest merytorycznych i formalnych (uniwersalność, jakość, interpretowalność, oddziaływanie zmiennych), jak i statystycznych. Kolejny etap obejmuje proces normalizacji i w pracy wykorzystano standaryzację. Następnie zgodnie z macierzą wystandaryzowanych zmiennych wejściowych formułuje się wzorzec o współrzędnych:

$$
z_{o j}=\left\{\begin{array}{l}
\max _{i}\left\{z_{i j}\right\} \operatorname{dla} z_{j}^{S} \\
\min _{i}\left\{z_{i j}\right\} \operatorname{dla} z_{j}^{D}, j=1,2, \ldots ; i=1,2, \ldots 1
\end{array}\right.
$$

oraz wyznacza się odległość od obiektu wzorcowego (przy obliczaniu odległości zastosowano metrykę euklidesową). Wyznaczona w ten sposób odległość i-tego obiektu od wzorca oznaczona $\mathrm{d}_{\mathrm{i} 0}$ stanowi podstawę dla syntetycznej miary rozwoju zdefiniowanej następująco:

$$
z_{i}=1-\frac{d_{i 0}}{d_{0}}, i=1,2, \ldots, m
$$

gdzie: $\mathrm{d}_{0}$ — odległość wzorca od antywzorca.

Wyznaczona w ten sposób miara syntetyczna określa pozycję każdego obiektu $\mathrm{w}$ rankingu. Im większa jest wartość takiej zmiennej, tym pozycja danego obiektu w rankingu będzie wyższa. Uporządkowane według malejących wartości miernika rozwoju obiekty dzielone są w kolejnym etapie na cztery grupy, które obejmują następujące przedziały (Adamowicz, Janulewicz, 2012, 17-28): 
- grupa 1 powiatów, dla których $z_{i} \geq z+S_{z}$,

- grupa 2 powiatów, dla których $z+S_{z}>z_{i} \geq z$,

- grupa 3 powiatów, dla których $z>z_{i} \geq z-S_{z}$,

- grupa 4 powiatów, dla których $z_{i}<z-S_{z}$.

Malejący charakter miernika świadczy o uporząakowaniu obiektów od tego, który charakteryzuje się największym poziomem badanego zjawiska według miernika rozwoju.

Podział tego samego zbioru obiektów może odbywać się według różnych kryteriów i wówczas do zbadania ich zgodności wykorzystywany jest wskaźnik zgodności wyników podziału, którego konstrukcja oparta jest na tablicy kontyngencji. Wskaźnik ten pozwala ocenić stopień podobieństwa wyników dwóch różnych klasyfikacji. W przypadku omawianego sposobu rozpatruje się tabelę kontyngencji 2x2, gdzie każdej parze obiektów przypisuje się wartości 1 lub 0 w zależności od ich przynależności do tej samej lub nie grupy, otrzymując tak zwane macierze przyporządkowania (Walesiak, 1990, 41-50).

Jedną z miar zależności pomiędzy zmiennymi nominalnymi jest współczynnik V-Cramera. Współczynnik ten jest wykorzystywany, gdy tabele kontyngencji mają bardziej złożone wymiary niż w przypadku tabel $2 \times 2$. Można go stosować również gdy liczby klas porównywanych klasyfikacji znacząco się różnią. Współczynnik ten jest dany wzorem:

$$
V=\sqrt{\frac{\chi^{2}}{n * \min (r-1), k-1)}}
$$

gdzie:

$x^{2}$ - wynik testu chi-kwadrat dla pary zmiennych,

$\mathrm{n}$ - liczba obserwacji,

$\mathrm{r}$ - liczba poziomów jednej zmiennej,

$\mathrm{k}$ - liczba drugiej jednej zmiennej

min $(r-1, k-1)$ — wartość $\mathrm{z}$ dwóch ( $\mathrm{r}-1)$ lub (k-1), która jest mniejsza.

Podział obiektów na grupy z wykorzystaniem omówionej metody poprzedzono oceną zdolności obliczonego syntetycznego miernika rozwoju do grupowania badanych jednostek. Najczęściej w procedurach taksonomicznych stosuje się wskaźnik G zaproponowany przez A. Sokołowskiego, który to wskaźnik stanowi podstawę oceny właściwości dyskryminacyjnych zmiennych (Cheba, 2010, 102-111) i wyrażony jest wzorem:

$$
G=1-\sum_{i=1}^{N-1} \min \left\{\frac{z_{i}-z_{i+1}}{R} ; \frac{1}{N-1}\right\}
$$


gdzie:

$\mathrm{R}=\max \left\{z_{i}\right\}-\min \left\{z_{i}\right\}$

$\mathrm{N}$ - liczba obiektów.

Wskaźnik $\mathrm{G}$ jest ustalony w taki sposób, że: $0 \leq \mathrm{G} \leq 1-\frac{1}{N-1}$

Do oceny uzyskanych wyników służy również całkowity indeks sylwetkowy GSI, który jest wyrażony następującym wzorem:

$$
G S I=\frac{1}{n} \sum_{i=1}^{n} \frac{b(i)-a(i)}{\max \{a(i) ; b(i)\}}
$$

gdzie:

a(i) - średnia odległość tego obiektu od pozostałych obiektów z tej samej klasy, b(i) — średnia odległość tego obiektu od obiektów należących do najbliższej klasy.

\section{Determinanty przestępczości w Polsce}

Przestępcze zachowania są wynikiem oddziaływania wielu czynników, na które często organy ścigania nie mają wpływu, a wszelkie istniejące badania nad przyczynami przestępczości są utrudnione ze względu na dwa istotne elementy. Pierwszym jest tak zwana ciemna liczba przestępstw, czyli taka, która nie jest zgłaszana na policję. Kolejnym jest różnorodność kwalifikacji prawnej czynów społecznie szkodliwych — w zależności od systemów prawnych oraz kwalifikacji w czasie danego czynu. Dlatego też determinanty przestępczości charakteryzują się znaczną złożonością czynników ze sfery między innymi: ekonomicznej, społecznej, demograficznej, geograficznej, biologicznej i kulturowej (Czarnecki, 2009, 21).

W literaturze wymienia się wiele czynników mogących mieć wpływ na przestępczość i ich jednoznaczne sklasyfikowanie nie jest zadaniem łatwym. Przeprowadzona analiza literatury z zakresu badania przyczynowości umożliwiła wskazanie najczęściej wymienianych determinant kryminogennych zachowań, które przedstawiono w tabeli 1.

W pracy zaproponowano podział wymienionych czynników na cztery ich rodzaje: ekonomiczne, społeczne, demograficzne oraz geograficzne. Siłę i charakter wpływu poszczególnych czynników na przestępczość zbadano, przeprowadzając analizę ich korelacji ze współczynnikiem przestępczości. Współczynnik przestępczości rozumiany jest jako liczba przestępstw stwierdzonych przez policję w zakończonych postępowaniach przygotowawczych (dane GUS pochodzą z komend wojewódzkich policji, które są publikowane w biuletynach statystycznych poszczególnych województw) przypadająca na 1000 mieszkańców danego obszaru. Wykorzystuje się go do porównywania przestępczości na wielu 
Tabela 1. Zmienne wraz z ich opisem oraz rodzajem

\begin{tabular}{|c|c|c|c|}
\hline & Opis & Źródło & $\begin{array}{c}\text { Rodzaj } \\
\text { czynnika }\end{array}$ \\
\hline $\mathrm{X}_{1}$ & $\begin{array}{l}\text { Stopa bezrobocia rejestrowanego w \% to stosunek } \\
\text { liczby bezrobotnych zarejestrowanych do liczby } \\
\text { cywilnej ludności aktywnej zawodowo (ogółem } \\
\text { oraz danej grupy) }\end{array}$ & Kiersztyn, 2008 & \multirow{7}{*}{ ekonomiczny } \\
\hline $\mathrm{X}_{2}$ & $\begin{array}{l}\text { Wydatki na edukacyjną opiekę wychowawczą na } \\
1000 \text { mieszkańców }\end{array}$ & Szczepaniec, 2011 & \\
\hline$X_{3}$ & $\begin{array}{l}\text { Wydatki na bezpieczeństwo publiczne na } 1000 \\
\text { mieszkańców }\end{array}$ & $\begin{array}{l}\text { Bieniek, Cichocki, } \\
\text { Szczepaniec, } 20012\end{array}$ & \\
\hline $\mathrm{X}_{4}$ & $\begin{array}{l}\text { Ludność w wieku nieprodukcyjnym na } 100 \text { osób } \\
\text { w wieku produkcyjnym }\end{array}$ & $\begin{array}{l}\text { Ellis, Beaver, } \\
\text { Wright, } 2009\end{array}$ & \\
\hline $\mathrm{X}_{5}$ & Dochody na 1 mieszkańca powiatu & Hołyst, 2016 & \\
\hline $\mathrm{X}_{6}$ & Wydatki na 1 mieszkańca powiatu & Hołyst, 2016 & \\
\hline $\mathrm{X}_{7}$ & $\begin{array}{l}\text { Przeciętne miesięczne wynagrodzenia brutto w rela- } \\
\text { cji do średniej krajowej }(\text { Polska=100) w powiecie }\end{array}$ & $\begin{array}{l}\text { Sztaudynger, Sztau- } \\
\text { dynger } 2004\end{array}$ & \\
\hline $\mathrm{X}_{8}$ & $\begin{array}{l}\text { Postępowania eksmisyjne i eksmisje z lokali } \\
\text { mieszkalnych w zasobach gminnych, stwierdzone } \\
\text { prawomocnie przez sąd jako ułamek wszystkich } \\
\text { mieszkań w powiecie }\end{array}$ & Hołyst, 2016 & \multirow{6}{*}{ społeczny } \\
\hline $\mathrm{X}_{9}$ & $\begin{array}{l}\text { Procent osób z wyższym wykształceniem na stano- } \\
\text { wisku radnego powiatu w ogólnej liczbie wszyst- } \\
\text { kich radnych powiatu }\end{array}$ & Kiersztyn, 2008 & \\
\hline $\mathrm{X}_{10}$ & $\begin{array}{l}\text { Gospodarstwa domowe korzystające ze środowisko- } \\
\text { wej pomocy społecznej według kryterium dochodo- } \\
\text { wego poniżej tego kryterium w ogólnej liczbie osób } \\
\text { korzystających z tej pomocy }\end{array}$ & Kiersztyn, 2008 & \\
\hline $\mathrm{X}_{11}$ & $\begin{array}{l}\text { Udział dzieci do lat } 17 \text {, na które rodzice otrzymują } \\
\text { zasiłek w ogólnej liczbie dzieci w tym wieku }\end{array}$ & $\begin{array}{l}\text { Sztaudynger, Sztau- } \\
\text { dynger } 2004\end{array}$ & \\
\hline $\mathrm{X}_{12}$ & Rodziny z więcej niż 4 dzieci do 24. roku życia & $\begin{array}{l}\text { Ellis, Beaver, } \\
\text { Wright, } 2009\end{array}$ & \\
\hline$X_{13}$ & $\begin{array}{l}\text { Śmiertelne wypadki samochodowe na } 10000 \\
\text { mieszkańców }\end{array}$ & Kądziołka, 2015 & \\
\hline $\mathrm{X}_{14}$ & $\begin{array}{l}\text { Zmiana liczby ludności w stosunku do roku po- } \\
\text { przedniego na } 1000 \text { mieszkańców }\end{array}$ & $\begin{array}{l}\text { Ellis, Beaver, } \\
\text { Wright, 2009Czar- } \\
\text { necki, } 2009\end{array}$ & \multirow{4}{*}{ demograficzny } \\
\hline $\mathrm{X}_{15}$ & Przyrost naturalny na 1000 mieszkańców & Czarnecki, 2009 & \\
\hline $\mathrm{X}_{16}$ & $\begin{array}{l}\text { Samotne matki w relacji do ogółu dorosłych } \\
\text { z dziećmi }\end{array}$ & Hołyst, 2016 & \\
\hline$X_{17}$ & Zgony niemowląt na 1000 urodzeń żywych & Hołyst, 2016 & \\
\hline
\end{tabular}




\begin{tabular}{|c|c|c|c|}
\hline $\mathrm{X}_{18}$ & $\begin{array}{l}\text { Współczynnik feminizacji — liczba kobiet na } 100 \\
\text { mężczyzn }\end{array}$ & $\begin{array}{l}\text { Ellis, Beaver, } \\
\text { Wright, } 2009\end{array}$ & \multirow{5}{*}{ demograficzny } \\
\hline $\mathrm{X}_{19}$ & Rozwody na 1000 mieszkańców & Hołyst, 2016 & \\
\hline $\mathrm{X}_{20}$ & $\begin{array}{l}\text { Nowotwór jako powód zgonu w przeliczeniu na } \\
\text { osobę }\end{array}$ & Hołyst, 2016 & \\
\hline $\mathrm{X}_{21}$ & $\begin{array}{l}\text { Wskaźnik obciążenia demograficznego — ludność } \\
\text { w wieku poprodukcyjnym na } 100 \text { osób w wieku } \\
\text { produkcyjnym }\end{array}$ & Park, Burgess, 1925 & \\
\hline $\mathrm{X}_{22}$ & Saldo migracji wewnątrzpowiatowych & Czarnecki, 2009 & \\
\hline $\mathrm{X}_{23}$ & Gęstość zaludnienia na 1 km² & Park, Burgess, 1925 & \multirow{9}{*}{ geograficzny } \\
\hline $\mathrm{X}_{24}$ & $\begin{array}{l}\text { Drogi gminne i powiatowe o twardej nawierzchni } \\
\text { na } 100 \mathrm{~km}^{2}\end{array}$ & $\begin{array}{l}\text { Siemaszko, Mar- } \\
\text { czewski, Gruszczyń- } \\
\text { ska, } 2015\end{array}$ & \\
\hline $\mathrm{X}_{25}$ & Lesistość w \% powierzchni & Park, Burgess, 1925 & \\
\hline $\mathrm{X}_{26}$ & Samochody osobowe na 1000 mieszkańców & Hołyst, 2016 & \\
\hline $\mathrm{X}_{27}$ & Ludność w miastach w \% ogółu ludności & Park, Burgess, 1925 & \\
\hline $\mathrm{X}_{28}$ & $\begin{array}{l}\text { Mieszkańcy placówek stacjonarnej pomocy społecz- } \\
\text { nej (łącznie z filiami) na } 1000 \text { mieszkańców }\end{array}$ & Hołyst, 2016 & \\
\hline $\mathrm{X}_{29}$ & Jednostki policyjne na $1000 \mathrm{~km}^{2}$ & Kądziołka, 2015 & \\
\hline $\mathrm{X}_{30}$ & $\begin{array}{l}\text { Grunty zabudowane i zurbanizowane - tereny } \\
\text { przemysłowe jako część powierzchni powiatu } \\
\text { ogółem }\end{array}$ & Kądziołka, 2015 & \\
\hline $\mathrm{X}_{31}$ & Grunty rolne - nieużytki jako część powierzchni & Hołyst, 2016 & \\
\hline
\end{tabular}

Źródło: opracowanie własne na podstawie literatury.

obszarach, które różnią się powierzchnią i liczbą ludności. Analiza korelacji została oparta na współczynnikach korelacji Pearsona i rang Spearmana, a ich istotność zweryfikowano, wykorzystując test istotności t-studenta - wyniki przedstawiono w tabeli 2. Uzyskane wyniki wskazują, że w przypadku czynników mających charakter ekonomiczny istotne byłoby uwzględnienie wydatków na edukacyjną opiekę wychowawczą, dochodów i wydatków powiatu na jednego mieszkańca. Społeczne czynniki, jakie należałoby wziąć pod uwagę przy analizowaniu zjawiska przestępczości, to liczba prawomocnie stwierdzonych eksmisji, liczba korzystających z pomocy społecznej gospodarstw domowych oraz udział dzieci do lat 17, na które rodzice otrzymują zasiłek, w ogólnej liczbie dzieci w tym wieku. Natomiast spośród czynników o naturze demograficznej statystycznie istotnym byłoby wybranie takich czynników, jak zmiana liczby ludności w stosunku do roku poprzedniego, liczba rozwodów oraz wskaźnik obciążenia demograficznego. Geograficznymi determinantami, które okazały się znaczące są: liczba jednostek policji jaka przypada na $1000 \mathrm{~km}^{2}$ oraz liczba mieszkańców placówek pomocy społecznej. 
Tabela 2. Współczynniki korelacji Pearsona i rang Spearmana między współczynnikiem przestępczości a poszczególnymi zmiennymi oraz wyniki testu ich istotności

\begin{tabular}{|c|c|c|c|c|}
\hline \multirow{2}{*}{ Zmienna } & \multicolumn{2}{|c|}{ WSPÓŁCZYNNIK PEARSONA } & \multicolumn{2}{|c|}{ WSPÓŁCZYNNIK SPEARMANA } \\
\hline & wartość & $\mathrm{p}$ value & wartość & $\mathrm{p}$ value \\
\hline $\mathrm{X}_{1}$ & 0,012631 & 0,8236 & 0,0672209 & 0,2349 \\
\hline $\mathrm{X}_{2}$ & $-0,4064855$ & 0 & $-0,2770158$ & 0 \\
\hline $\mathrm{X}_{3}$ & $-0,4597818$ & 0 & $-0,1955931$ & 0,0005 \\
\hline $\mathrm{X}_{4}$ & $-0,2390523$ & 0 & $-0,3626648$ & 0 \\
\hline $\mathrm{X}_{5}$ & $-0,1855565$ & 0,001 & $-0,1464527$ & 0,0094 \\
\hline $\mathrm{X}_{6}$ & $-0,1923298$ & 0,0006 & $-0,1521875$ & 0,0069 \\
\hline $\mathrm{X}_{7}$ & 0,0523828 & 0,3549 & 0,2127401 & 0,0001 \\
\hline $\mathrm{X}_{8}$ & 0,1462207 & 0,0095 & 0,1860294 & 0,0009 \\
\hline $\mathrm{X}_{9}$ & $-0,0399803$ & 0,4802 & 0,0513739 & 0,3642 \\
\hline $\mathrm{X}_{10}$ & 0,1250238 & 0,0267 & 0,0741124 & 0,1903 \\
\hline $\mathrm{X}_{11}$ & $-0,1849649$ & 0,001 & $-0,3324546$ & 0 \\
\hline $\mathrm{X}_{12}$ & $-0,1204569$ & 0,0329 & $-0,2760874$ & 0 \\
\hline $\mathrm{X}_{13}$ & 0,0914833 & 0,1057 & 0,0990299 & 0,0798 \\
\hline $\mathrm{X}_{14}$ & 0,1505071 & 0,0075 & 0,1364504 & 0,0155 \\
\hline $\mathrm{X}_{15}$ & 0,031549 & 0,5776 & 0,0132799 & 0,8147 \\
\hline $\mathrm{X} 1_{6}$ & 0,0521365 & 0,3572 & 0,2080686 & 0,0002 \\
\hline $\mathrm{X}_{17}$ & 0,0658766 & 0,2444 & 0,0563096 & 0,3199 \\
\hline $\mathrm{X}_{18}$ & 0,0337753 & 0,551 & 0,0271629 & 0,6316 \\
\hline $\mathrm{X}_{19}$ & 0,1461523 & 0,0095 & 0,3547802 & 0 \\
\hline $\mathrm{X}_{20}$ & 0,0419701 & 0,4586 & 0,1616224 & 0,0041 \\
\hline$X_{21}$ & $-0,140699$ & 0,0126 & $-0,1232644$ & 0,029 \\
\hline $\mathrm{X}_{22}$ & 0,1076514 & 0,0567 & 0,2094624 & 0,0002 \\
\hline $\mathrm{X}_{23}$ & 0,0269483 & 0,6343 & 0,0050816 & 0,9285 \\
\hline$X_{24}$ & $-0,0024012$ & 0,9662 & $-0,1278308$ & 0,0235 \\
\hline $\mathrm{X}_{25}$ & 0,0757154 & 0,1808 & 0,1263777 & 0,0251 \\
\hline $\mathrm{X}_{26}$ & 0,0414359 & 0,4644 & 0,0399761 & 0,4803 \\
\hline $\mathrm{X}_{27}$ & $-0,077488$ & 0,1708 & 0,2120969 & 0,0002 \\
\hline
\end{tabular}

Ekonomia - Wroclaw Economic Review 26/1, 2020

(C) for this edition by CNS 


\begin{tabular}{|l|c|c|c|c|}
\hline $\mathrm{X}_{28}$ & 0,1264895 & 0,025 & 0,035643 & 0,5292 \\
\hline $\mathrm{X}_{29}$ & 0,1463566 & 0,0094 & 0,1799984 & 0,0014 \\
\hline $\mathrm{X}_{30}$ & 0,0774398 & 0,1711 & 0,1879483 & 0,0008 \\
\hline $\mathrm{X}_{31}$ & 0,0190097 & 0,7372 & 0,1248962 & 0,0269 \\
\hline
\end{tabular}

Źródło: opracowanie własne.

\section{Wyniki badań empirycznych}

Badanie zjawiska przestępczości przeprowadzono na podstawie danych statystycznych w 314 powiatach Polski bez uwzględnienia miast na prawach powiatu za 2012 roku, udostępnionych na stronie internetowej Głównego Urzędu Statystycznego. Poszczególne powiaty zostały oznaczone symbolami: P1-P314, a przyjęta kolejność jest arbitralna i nie ma wpływu na uzyskane wyniki. Ze zbioru potencjalnych zmiennych wykluczono te, dla których współczynnik zmienności był nie większy niż $10 \%$, są to bowiem zmienne quasi-stałe, czyli niemające zdolności determinacji zjawisk. Wyeliminowanymi zmiennymi na tym etapie okazały się zmienne $X_{4}$ (ludność w wieku nieprodukcyjnym na 100 osób w wieku produkcyjnym) i $X_{18}$ (współczynnik feminizacji - liczba kobiet na 100 mężczyzn w 2012 roku). W kolejnym etapie na podstawie macierzy korelacji zbadano wzajemne powiązania zmiennych i przeprowadzono ich podział na zmienne centralne, satelitarne i izolowane. Przy wartości krytycznej współczynnika korelacji równej $r^{*}=0,1107$ przeprowadzono pełną procedurę iteracyjną, której wyniki przedstawiono w tabeli 3.

Tabela 3. Wyniki wyboru zmiennych diagnostycznych z zastosowaniem metody parametrycznej

\begin{tabular}{|c|c|}
\hline CENTRALNE & SATELITARNE \\
\hline$X_{11}$ & $\mathrm{X} 1, \mathrm{X} 2, \mathrm{X} 3, \mathrm{X} 5, \mathrm{X} 6, \mathrm{X} 7, \mathrm{X} 8, \mathrm{X} 9, \mathrm{X} 10, \mathrm{X} 12, \mathrm{X} 14, \mathrm{X} 24, \mathrm{X} 27, \mathrm{X} 28, \mathrm{X} 29, \mathrm{X} 30, \mathrm{X} 31$ \\
\hline $\mathrm{X}_{21}$ & $\mathrm{X} 16, \mathrm{X} 25$ \\
\hline $\mathrm{X}_{13}$ & $\mathrm{X} 6$ \\
\hline
\end{tabular}

Źródło: opracowanie własne na podstawie obliczeń otrzymanych z zastosowaniem programu Gretl i Excel.

Ostatecznie jako zmienne diagnostyczne stanowiące reprezentantów wyjściowego zbioru zmiennych wybrano: $\mathrm{X}^{11}, \mathrm{X}^{13}, \mathrm{X}^{17}, \mathrm{X}^{21}$ (zmienna $\mathrm{X}^{17}$ jest zmienną izolowaną). Ich opis i charakter oraz wyznaczone wielkości wzorca $\mathrm{i}$ antywzorca przedstawiono w następujących tabelach: 
Tabela 4. Zmienne diagnostyczne warunkujące poziom zjawiska przestępczości wraz z ich opisem

\begin{tabular}{|c|l|l|c|}
\hline Zmienna & Rodzaj & \multicolumn{1}{|c|}{ Opis } & Charakter \\
\hline $\mathrm{X}_{11}$ & społeczne & $\begin{array}{l}\text { Udział dzieci do lat 17, na które rodzice otrzymują } \\
\text { zasiłek, w ogólnej liczbie dzieci w tym wieku w 2012 } \\
\text { roku }\end{array}$ & stymulanta \\
\hline $\mathrm{X}_{13}$ & społeczne & $\begin{array}{l}\text { Śmiertelne wypadki samochodowe na 10 000 miesz- } \\
\text { kańców w 2012 roku }\end{array}$ & stymulanta \\
\hline $\mathrm{X}_{17}$ & $\begin{array}{l}\text { demogra- } \\
\text { ficzne }\end{array}$ & $\begin{array}{l}\text { Zgony niemowląt na 1000 urodzeń żywych w 2012 } \\
\text { roku }\end{array}$ & stymulanta \\
\hline $\mathrm{X}_{21}$ & $\begin{array}{l}\text { demogra- } \\
\text { ficzne }\end{array}$ & $\begin{array}{l}\text { Wskaźnik obciążenia demograficznego - ludność } \\
\text { w wieku poprodukcyjnym na 100 osób w wieku pro- } \\
\text { dukcyjnym w 2012 roku }\end{array}$ & stymulanta \\
\hline
\end{tabular}

Źródło: opracowanie własne.

Tabela 5. Wzorzec i antywzorzec

\begin{tabular}{|c|c|c|c|c|}
\hline & $\mathrm{X} 11$ & $\mathrm{X} 13$ & $\mathrm{X} 17$ & $\mathrm{X} 21$ \\
\hline Wzorzec & 2,462892364 & 3,0029 & 3,545 & 4,2933 \\
\hline Antywzorzec & $-2,809617954$ & $-1,847$ & $-1,741$ & $-2,56$ \\
\hline $\begin{array}{c}\text { Odległość wzorca od } \\
\text { antywzorca }\end{array}$ & \multicolumn{3}{|c}{11,23538942} \\
\hline
\end{tabular}

Źródło: opracowanie własne na podstawie obliczeń wykonanych w programie Excel.

Zamieszczone wyniki służą obliczeniu odległości każdego powiatu od wzorca. W tym celu wykorzystuje się odległość euklidesową. Podział powiatów na grupy poprzedzono oceną zdolności obliczonego syntetycznego miernika rozwoju do grupowania badanych jednostek. Obliczona miara G, określająca zdolność miernika rozwoju do grupowania badanych powiatów, wyniosła 0,506253, co świadczy o tym, że miernik ten ma dość dobrą zdolność do podziału powiatów na grupy typologiczne. Wyniki grupowania powiatów zostały przedstawione w tabeli 6 .

Otrzymane wyniki klasyfikowania powiatów ze względu na poziom zjawiska przestępczości porównano ze współczynnikiem przestępczości jako opinią ekspertów w celu zweryfikowania poprawności i przydatności klasyfikacji. Współczynnik ten jest miarą służącą ocenie i porównaniu zjawiska przestępczości w różnych jednostkach terytorialnych, które różnią się powierzchnią oraz stanem ludności. Dalej zaprezentowano przestrzenne zróżnicowanie powiatów według eksperckiej oceny opartej na współczynniku przestępczości oraz przeprowadzonego własnego rankingu i grupowania. 
Tabela 6. Klasyfikacja powiatów według taksonomicznego miernika rozwoju zjawiska przestępczości

\begin{tabular}{|c|c|c|c|}
\hline Grupa & Liczba & Przedział & Powiaty \\
\hline Grupa 1 & 54 & $0,457-1$ & $\begin{array}{l}\text { łęczycki, poddębicki, parczewski, proszowicki, przeworski, radom- } \\
\text { szczański, brzeziński, ostrowski, tatrzański, skierniewicki, san- } \\
\text { domierski, wałbrzyski, ząbkowicki, węgorzewski, tomaszowski, } \\
\text { pleszewski, sokołowski, węgrowski, starachowicki, zgierski, kraś- } \\
\text { nicki, niżański, konecki, białobrzeski, lipski, jaworski, siemiatycki, } \\
\text { mławski, piotrkowski, wieruszowski, radzyński, górowski, bielski, } \\
\text { strzeliński, rycki, łomżyński, kazimierski, puławski, zawierciań- } \\
\text { ski, chełmski, mogileński, makowski, kozienicki, sokólski, kolski, } \\
\text { skarżyski, świdnicki, częstochowski, dębicki, olecki, hrubieszowski, } \\
\text { opoczyński, przysuski, łowicki }\end{array}$ \\
\hline Grupa 2 & 92 & $0,375-0,457$ & $\begin{array}{l}\text { augustowski, ostrowiecki, przasnyski, janowski, łosicki, zambrowski, } \\
\text { sieradzki, jędrzejowski milicki, opolski, kamiennogórski, szydłowie- } \\
\text { cki, płoński, zamojski, płocki, łaski, tarnogórski, włodawski, rawski, } \\
\text { ostrołęcki, miechowski, kętrzyński, tarnobrzeski, pajęczański, kłodzki, } \\
\text { strzyżowski, kutnowski, lubartowski, pułtuski, żyrardowski, lidzbarski, } \\
\text { krasnostawski, buski, gorlicki, bialski, kluczborski, żywiecki, jelenio- } \\
\text { górski, sierpecki, suwalski, wołowski, iławski, legnicki, nowosolski, } \\
\text { słupecki, rypiński, grójecki, malborski, rawicki, pabianicki, krośnień- } \\
\text { ski, moniecki, wyszkowski, tczewski, opatowski, wałecki, tomaszow- } \\
\text { ski, siedlecki, wysokomazowiecki, świdwiński, bieszczadzki, kaliski, } \\
\text { zwoleński, łańcucki, sławieński, pińczowski, bocheński, nyski, mysz- } \\
\text { kowski, ostrowski, biłgorajski, staszowski, łukowski, dzierżoniowski, } \\
\text { kołobrzeski, białostocki, opolski, brzeski, gostyniński, lipnowski, da-- } \\
\text { browski, włoszczowski, łódzki, namysłowski, radomski, świebodziński, } \\
\text { braniewski, mrągowski, kościański, oleśnicki, trzebnicki, nowotarski }\end{array}$ \\
\hline Grupa 3 & 119 & $0,293-0,375$ & $\begin{array}{l}\text { krośnieński, żarski, wieluński, strzelecki, kielecki, suski, nidzicki, } \\
\text { ropczycko-sędziszowski, olsztyński, radziejowski białogardzki, żu- } \\
\text { romiński, strzelecko-drezdenecki, starogardzki, łobeski, kępiński } \\
\text {,gryficki, jarociński, grudziądzki, głubczycki, myślenicki, ostródzki, } \\
\text { aleksandrowski, koniński, rzeszowski, tucholski, lwówecki, golubsko- } \\
\text {-dobrzyński, drawski, bartoszycki, średzki, szczycieński, brzozowski, } \\
\text { lubelski, wąbrzeski, kłobucki, żagański, nakielski, raciborski, lub- } \\
\text { liniecki, mielecki, międzyrzecki, giżycki, nowotomyski, gliwicki, } \\
\text { hajnowski, włocławski, tarnowski, nowodworski, sejneński, turecki, } \\
\text { cieszyński, zgorzelecki, chojnicki, oświęcimski, kolbuszowski, socha- } \\
\text { czewski, kamieński, jasielski, międzychodzki, bełchatowski, garwo- } \\
\text { liński, będziński, sztumski, szczecinecki, inowrocławski, wodzisław- } \\
\text { ski, zduńskowolski, ciechanowski, średzki, leszczyński, kościerski, } \\
\text { choszczeński, chrzanowski, pilski, brzeski, ostrzeszowski, wadowi- } \\
\text { cki, piski, gołdapski, gnieźnieński, nowosądecki, wielicki, stargardzki, } \\
\text { czarnkowsko-trzcianecki, myśliborski, olkuski, sępoleński, obornicki, } \\
\text { lubaczowski, nowomiejski, żniński, elbląski, brodnicki, przemyski, } \\
\text { gorzowski, oleski, chełmiński, leżajski, krakowski, stalowowolski, } \\
\text { kartuski, jarosławski, kwidzyński, prudnicki, miński, świdnicki, człu- } \\
\text { chowski, bytowski, oławski, grajewski, kolneński, chodzieski, gryfiń- } \\
\text { ski, otwocki, krotoszyński, śremski, sanocki }\end{array}$ \\
\hline
\end{tabular}




\begin{tabular}{|c|c|l|l}
\hline & & $\begin{array}{l}\text { wrocławski, wschowski, lęborski, pucki, bielski, toruński, sulęciń- } \\
\text { ski, zielonogórski, kędzierzyńsko-kozielski, wrzesiński, bolesławie- } \\
\text { cki, wolsztyński, limanowski, świecki, wągrowiecki, słupski, gro- } \\
\text { dziski, słubicki, ełcki, leski, goleniowski, złotowski, działdowski, } \\
\text { polkowicki, bydgoski, lubiński, lęczyński, lubański, pszczyński, py- } \\
\text { rzycki, głogowski, rybnicki, pruszkowski, warszawski, wołomiński, } \\
\text { gostyński, szamotulski, złotoryjski, wejherowski, koszaliński, legio- } \\
\text { nowski, mikołowski, grodziski, krapkowicki, piaseczyński, gdański, } \\
\text { bieruńsko-lędziński, poznański, policki }\end{array}$ \\
\hline
\end{tabular}

Źródło: opracowanie własne.

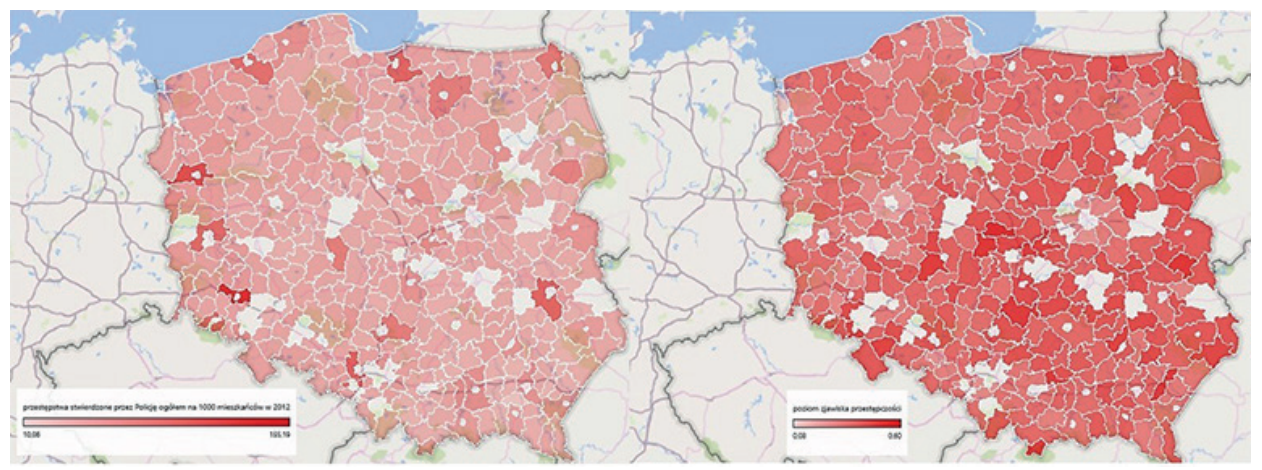

Rysunek 1. Porównanie zagrożenia przestępczością na podstawie wskaźnika przestępczości oraz syntetycznej miary rozwoju w analizowanych powiatach w Polsce w 2012 roku

Źródło: opracowanie własne na podstawie danych GUS oraz obliczeń wykonanych w programie Excel.

Na podstawie zaprezentowanych map można zauważyć, że północno-zachodnia część Polski charakteryzuje się zwiększonym natężeniem przestępczości. Również na podstawie utworzonej mapy zgodnie z klasyfikacją powiatów według taksonomicznego miernika rozwoju zjawiska przestępczości wyraźnie można dostrzec, że poziom tego zjawiska jest największy dla części Polski zachodniej. W obu przypadkach na mapach Polska zachodnia została oznaczona tymi samymi kolorami, co świadczy o tym samym poziomie zagrożenia przestępczością. Najmniej zagrożona przestępczością w przypadku współczynnika przestępczości wydaje się Polska południowa lub południowo-wschodnia. W przypadku syntetycznej miary rozwoju najsłabszy poziom zjawiska przestępczości występuje w Polsce środkowo-wschodniej, co świadczy o zbliżonych wynikach uzyskanych w obu przypadkach. Podsumowując, należy uznać, iż klasyfikacja powiatów według syntetycznej miary rozwoju niektórych regionach zgadza się z danymi Głównego Urzędu Statystycznego odnośnie do natężenia przestępstw.

Poniżej zaprezentowano tablicę kontyngencji dla analizowanych powiatów, gdzie A oznacza klasyfikację według współczynnika przestępczości, a B — według syntetycznej miary rozwoju. Zamieszczone tablice posłużyły do obliczenia współczynnika V-Cramera. 
Tabela 7. Tablica kontyngencji wyników klasyfikacji powiatów według syntetycznej miary rozwoju oraz według współczynnika przestępczości

\begin{tabular}{|c|c|c|c|c|c|}
\hline B & 1 & 2 & 3 & 4 & SUMA \\
\hline 1 & 9 & 14 & 17 & 14 & 54 \\
\hline 2 & 21 & 26 & 19 & 26 & 92 \\
\hline 3 & 33 & 25 & 27 & 34 & 119 \\
\hline 4 & 15 & 14 & 16 & 4 & 49 \\
\hline SUMA & 78 & 79 & 79 & 78 & 314 \\
\hline
\end{tabular}

Źródło: opracowanie własne.

Tabela 8. Wskaźniki podobieństwa grup typologicznych powiatów według wskaźnika przestępczości oraz syntetycznej miary rozwoju

\begin{tabular}{|c|c|c|c|c|c|}
\hline A & 1 & 2 & 3 & 4 & SUMA \\
\hline 1 & 1,452 & 0,013 & 0,858 & 0,026 & 2,349 \\
\hline 2 & 0,150 & 0,352 & 0,743 & 0,433 & 1,678 \\
\hline 3 & 0,400 & 0,815 & 0,289 & 0,667 & 2,170 \\
\hline 4 & 0,657 & 0,227 & 1,094 & 5,486 & 7,464 \\
\hline SUMA & 2,660 & 1,406 & 2,983 & 6,612 & 13,661 \\
\hline
\end{tabular}

Źródło: opracowanie własne na podstawie obliczeń wykonanych w programie Excel.

Współczynnik V-Cramera przyjmuje wartość 0,1204 , co świadczy o niskiej zależności, natomiast wartość statystyki testowej równa się 13,66 przy wartości $\mathrm{p}=0,1349^{1}$. Nie ma zatem podstaw do odrzucenia hipotezy zerowej mówiącej o nieistnieniu zależności obydwu klasyfikacji. Wynik ten nie świadczy całkowicie o nieistnieniu jakiegokolwiek związku między dwiema klasyfikacjami, mówi jedynie o małej mocy testu statystycznego, to znaczy, że jest on nieinformacyjny.

\section{Wykorzystanie metody Warda jako narzędzia służącego wyodrębnieniu jednorodnych grup powiatów}

Wykorzystując metodę Warda, z wskazanymi w poprzednim etapie analizy zmiennymi diagnostycznymi powiaty podzielono na dziesięć grup (Grajewski, 2006, 155-156). Na zamieszczonym dendogramie przerywaną linią oznaczono przyjęte miejsce jego podziału (Kądziołka, 2016, 31-43).

1 Obliczenia wykonano za pomocą programu R. 


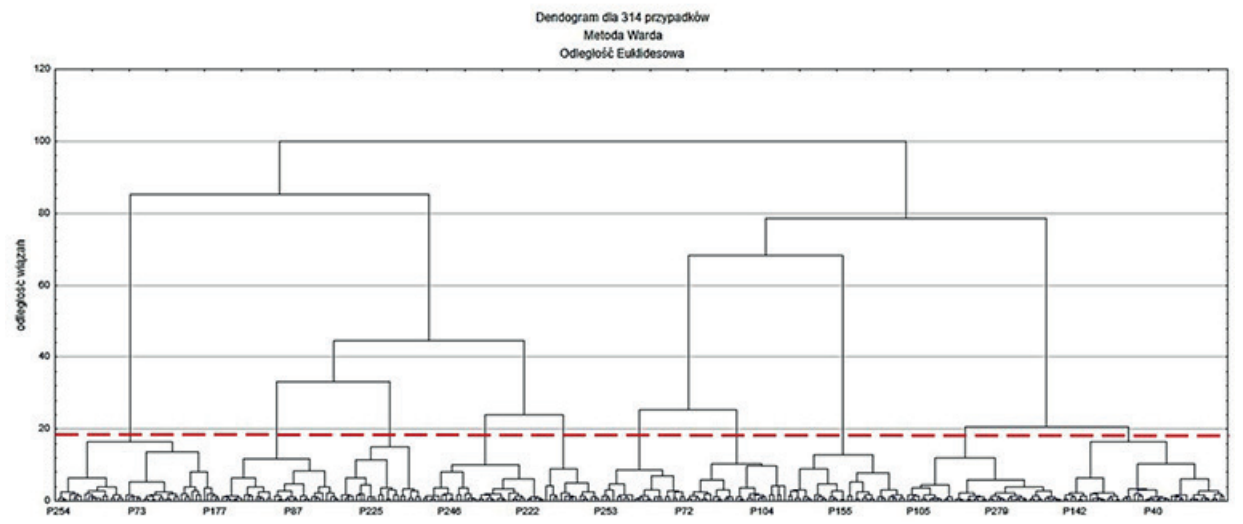

Rysunek 2. Dendogram uzyskany metodą Warda w programie STATISTICA

Źródło: opracowanie własne.

Analizując dendogram „od dołu”, gdzie każdy obiekt stanowił odrębną grupę, łączymy je kolejno, rozpoczynając od tych najbliżej sobie położonych. Liczby na osi pionowej są odległościami, a długości linii, które łączą poszczególne skupienia powiatów, odpowiadają najmniejszym odległościom. W kolejnych etapach łączymy coraz to więcej obiektów, agregując je w większe skupienia, aż wszystkie jednostki zostaną połączone $w$ jedno skupienie. Na dendogramie na osi pionowej odłożone są zestandaryzowane odległości (Wałęga, Krzanowski, Chmielowski, 2009, 67-82). Z dendogramu można odczytać, w jakiej kolejności łączono obiekty, jakie skupienia łączono w n-tym grupowaniu, jaka jest liczebność grup; wybierając daną odległość, można ustalić dowolną liczbę grup.

W celu precyzyjniejszego określenia miejsca punktu odcięcia posłużono się również wykresem przebiegu aglomeracji, który przedstawiono na rysunku 3.

Wykres pokazuje odległości między skupieniami w momencie ich łączenia. Wyraźne spłaszczenie lub bardziej niż dotychczas pionowa linia oznacza, że w tym właśnie miejscu skupienia są oddalone, a tym samym jest to odpowiedni punkt odcięcia. Na wykresie wyraźnie widać, że arbitralnie przyjęty poziom odcięcia na podstawie otrzymanego dendogramu zgadza się z poziomem odcięcia, który można zauważyć na podstawie wykresu odległości wiązań względem etapów wiązania. Punkt odcięcia leży pomiędzy krokiem 290 a 300. Jego rzędna odpowiada odległości między wiązaniami około 20, dlatego możliwe jest wyodrębnienie 10 skupień. W celu zaprezentowania miejsca odcięcia na wykresie została umieszczona przerywana linia na wysokości odcięcia. 


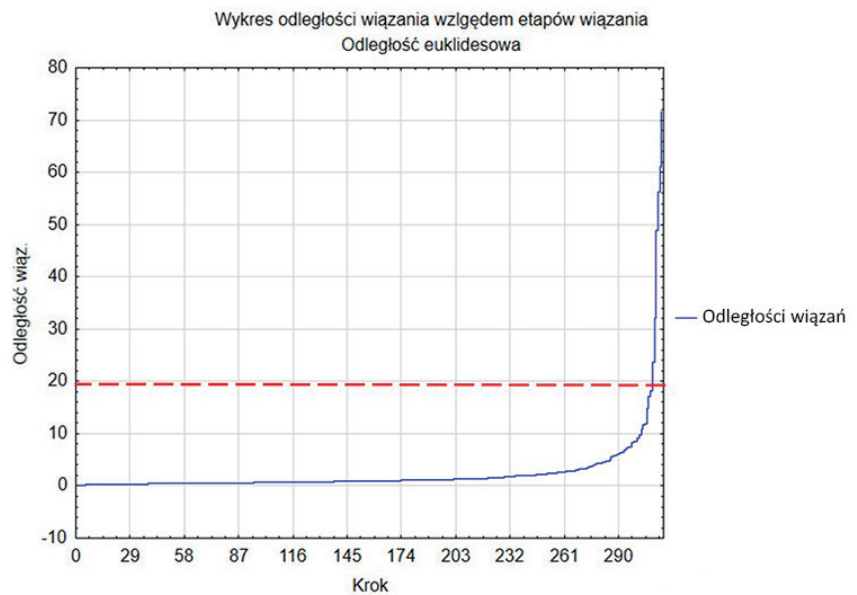

Rysunek 3. Wykres przebiegu aglomeracji otrzymany w programie STATISTICA

Źródło: opracowanie własne.

Hierarchiczna procedura grupowania daje możliwość ustalenia podobnych do siebie ze względu na cechy powiatów. Analizując kolejność łączeń poszczególnych powiatów, należy zauważyć, że najbardziej podobne do siebie, ze względu na strukturę charakteryzujących cech, są powiaty: P141 — pułtuski i P185 — tarnobrzeski; P71 - strzelecko-drezdenecki i P247 - bartoszycki; P83 - łódzki wschodni i P304 - kołobrzeski; P120 - garwoliński i P298 - choszczeński. W przypadku wymienionych par powiatów odległość między nimi nie była większa niż 0,25 . Wyniki grupowania uzyskane na podstawie omawianych badań zamieszczono w tabeli 9 oraz na rysunku 4.

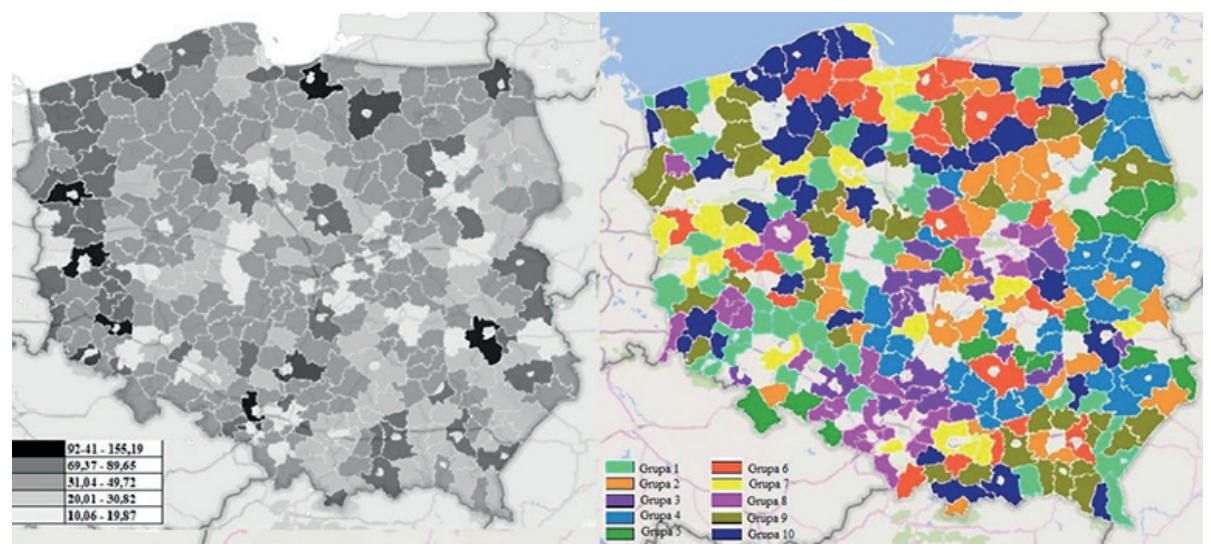

Rysunek 4. Porównanie rozmieszczenia przestępczości na podstawie wskaźnika przestępczości oraz wyników grupowania powiatów metodą Warda w 2012 roku

Źródło: opracowanie własne. 
Tabela 9. Klasyfikacja powiatów metodą Warda ze względu na poziom zjawiska przestępczości

\begin{tabular}{|c|c|c|}
\hline $\begin{array}{l}\text { Numer } \\
\text { grupy }\end{array}$ & $\begin{array}{l}\text { Liczba } \\
\text { powiatów } \\
\text { w grupie }\end{array}$ & Powiaty \\
\hline 1 & 44 & $\begin{array}{l}\text { kętrzyński, świdwiński, gorlicki, przemyski, kaliski, rypiński, lipnowski, śrem- } \\
\text { ski, tucholski, obornicki, gryficki, nakielski, sztumski, grudziądzki, słupecki, } \\
\text { zambrowski, bieszczadzki, milicki, średzki, trzebnicki, wołowski, świebodziń- } \\
\text { ski, legnicki, wałecki, sławieński, tarnobrzeski, pułtuski, żarski, nowosolski, } \\
\text { namysłowski, oleśnicki, kolski, kamiennogórski, strzelecki, kluczborski, jele- } \\
\text { niogórski, krośnieński, strzeliński, jaworski, parczewski, przeworski, olecki, } \\
\text { niżański, górowski }\end{array}$ \\
\hline 2 & 32 & $\begin{array}{l}\text { suwalski, łomżyński, szydłowiecki, makowski, radzyński, chełmski, ostrołę- } \\
\text { cki, pleszewski, białobrzeski, węgrowski, mławski, wieruszowski, dębicki, } \\
\text { mogileński, przasnyski, strzyżowski, opoczyński, lidzbarski, płoński, piot- } \\
\text { rkowski, rycki, tomaszowski, sandomierski, kraśnicki, ostrowski, węgorzew- } \\
\text { ski, proszowicki, łęczycki, tatrzański, brzeziński, skierniewicki, ząbkowicki }\end{array}$ \\
\hline 3 & 22 & $\begin{array}{l}\text { zawierciański, skarżyski, miechowski, pabianicki, otwocki, miński, zduń- } \\
\text { skowolski, opatowski, myszkowski, łaski, sierpecki, rawski, radomszczański, } \\
\text { poddębicki, częstochowski, kutnowski, tarnogórski, opolski, zgierski, wałbrzy- } \\
\text { ski, żyrardowski, świdnicki }\end{array}$ \\
\hline 4 & 33 & $\begin{array}{l}\text { kazimierski, buski, sokólski, łosicki, lipski, pińczowski, sejneński, włosz- } \\
\text { czowski, tomaszowski, kolneński, żuromiński, przysuski, łukowski, zwoleń- } \\
\text { ski, bialski, staszowski, siedlecki, augustowski, jędrzejowski, pajęczański, } \\
\text { sieradzki, włodawski, lubartowski, opolski, zamojski, janowski, moniecki, } \\
\text { biłgorajski, kłobucki, gostyniński, wysokomazowiecki, wieluński, aleksan- } \\
\text { drowski }\end{array}$ \\
\hline 5 & 15 & $\begin{array}{l}\text { hajnowski, bielski, siemiatycki, krasnostawski, ostrowiecki, konecki, staracho- } \\
\text { wicki, sokołowski, hrubieszowski, puławski, łowicki, kłodzki, nyski, głubczy- } \\
\text { cki, dzierżoniowski }\end{array}$ \\
\hline 6 & 23 & $\begin{array}{l}\text { olsztyński, iławski, starogardzki, kartuski, kielecki, kościerski, leszczyński, } \\
\text { myślenicki, brzeski, rawicki, kościański, braniewski, mrągowski, wyszkowski, } \\
\text { żywiecki, płocki, kozienicki, nowomiejski, dąbrowski, elbląski, bytowski, rze- } \\
\text { szowski, sulęciński }\end{array}$ \\
\hline 7 & 27 & $\begin{array}{l}\text { średzki, nowodworski, nowotomyski, bocheński, tczewski, malborski, bełcha- } \\
\text { towski, gorzowski, kwidzyński, toruński, zielonogórski, łęczyński, bydgoski, } \\
\text { grójecki, kołobrzeski, łódzki, pilski, wielicki, słubicki, nowodworski, krakow- } \\
\text { ski, międzyrzecki, bieruńsko-lędziński, pszczyński, pucki, gdański, wrocław- } \\
\text { ski }\end{array}$ \\
\hline 8 & 32 & $\begin{array}{l}\text { będziński, kędzierzyński, olkuski, chrzanowski, oleski, prudnicki, świdnicki, } \\
\text { gliwicki, raciborski, wodzisławski, oświęcimski, cieszyński, lubliniecki, so- } \\
\text { chaczewski, brzeski, zgorzelecki, policki, poznański, wołomiński, polkowicki, } \\
\text { rybnicki, piaseczyński, bielski, oławski, krapkowicki, pruszkowski, lubiński, } \\
\text { mikołowski, warszawski, grodziski, legionowski, głogowski }\end{array}$ \\
\hline
\end{tabular}




\begin{tabular}{|c|l|l|}
\hline \multirow{2}{*}{42} & $\begin{array}{l}\text { grajewski, piski, kolbuszowski, limanowski, sanocki, jarosławski, brzozowski, } \\
\text { żniński, jasielski, włocławski, lubaczowski, leżajski, radziejowski, ostródzki, } \\
\text { drawski, tarnowski, łobeski, suski, białogardzki, jarociński, kępiński, golubsko- } \\
\text {-dobrzyński, gryfiński, goleniowski, międzychodzki, gnieźnieński, ciechanow- } \\
\text { ski, krotoszyński, wschowski, turecki, wąbrzeski, czarnowsko-trzcianecki, sę- } \\
\text { poleński, stargardzki, mielecki, szczecinecki, krośnieński, ostrowski, łańcucki, } \\
\text { białostocki, żagański, lwówecki }\end{array}$ \\
\hline 10 & $\begin{array}{l}\text { koniński, chojnicki, nidzicki, radomski, szczycieński, nowotarski, nowosąde- } \\
\text { cki, działdowski, ostrzeszowski, giżycki, choszczeński, garwoliński, gołdapski, } \\
\text { ropczycko-sędziowski, bartoszycki, strzelecko-drezdenecki, ełcki, słupski, człu- } \\
\text { chowski, grodziski, koszaliński, wejherowski, złotowski, wolsztyński, świecki, } \\
\text { wągrowiecki, lęborski, chełmiński, brodnicki, leski, gostyński, pyrzycki, zło- } \\
\text { toryjski, lubański, wrzesiński, myśliborski, chodzieski, kamieński, wadowicki, } \\
\text { lubelski, stalowowolski, inowrocławski, szamotulski, bolesławiecki }\end{array}$ \\
\hline 44 &
\end{tabular}

Źródło: opracowanie własne.

Utworzone metodą Warda grupy w większości tworzą jednorodne skupienia, co świadczy o tym, że sąsiadujące z sobą powiaty mają podobną wewnętrzną strukturę ze względu na zmienne diagnostyczne. Porównując rozmieszczenie powiatów ze względu na wskaźnik przestępczości i uzyskane metodą Warda wyniki, można zauważyć, że w większości grupy uzyskane metodą Warda tworzą skupiska, tak jak w przypadku mapy Polski, ze względu na natężenie przestępczością. Może to świadczyć o tym, iż na przestępczość w poszczególnych częściach Polski mają wpływ te same czynniki z podobnym skutkiem. Można zakładać, że wschodnia część Polski jest najmniej zagrożona przestępczością, co widać na ilustracji natężenia przestępczością, a która w jednorodny sposób jest wyodrębniona kolorami na mapie metodą Warda (Błażejczyk, 2018, 6390). Końcowym etapem procesu grupowania jest ocena uzyskanych wyników. Ocenie wyników służy wyznaczenie indeksu sylwetkowego GSI, który przyjął wartość 0,118 . Wartość ta świadczy, że nie wykryto struktury w zastosowanym podziale na grupy. Wskazane byłoby zastosowanie innego podziału lub wykorzystanie innej metody hierarchicznego grupowania, z czego wynika, że metoda Warda ma słabą skuteczność i dopasowanie w przypadku grupowania powiatów ze względu na przestępczość.

\section{Wnioski}

Celem pracy była ocena struktury przestrzennego zróżnicowania przestępczości i analiza czynników na nie wpływających z wykorzystaniem metod wielowymiarowej analizy porównawczej. Artykuł miał za zadanie ocenę przydatności metod wielowymiarowych w tworzeniu klasyfikacji powiatów ze względu na stopień nasilenia przestępczością. Z przeprowadzonych badań wyciągnięto wnioski. 
1. Metody wielowymiarowej analizy danych są doskonałym narzędziem do badania wielu obiektów pod względem jednej zmiennej, którą można scharakteryzować wieloma cechami. W zależności od potrzeby analizy przydatne okazują się metody porządkowania oraz metody grupowania. Metody porządkowania umożliwiają badaczowi wyodrębnienie hierarchii obiektów ze względu na określone z góry kryterium, a problem pogrupowania jednostek ma znaczenie drugorzędne. Metody porządkowania służą określeniu intensywności analizowanego zjawiska, co może posłużyć działaniom prewencyjnym zjawiska przestępczości. $\mathrm{Z}$ kolei celem metod grupowania jest stworzenie jak najbardziej podobnych grup skupień, dzięki czemu staje się możliwe wyodrębnienie jednostek podobnych do siebie ze względu na pewne cechy, co może okazać się przydatne w poszukiwaniu rozwiązań pewnych problemów, tudzież zjawiska przestępczości.

2. Przeprowadzona na wstępie analiza korelacji poszczególnych zmiennych ze współczynnikiem przestępczości nie wskazała jednoznacznie na ścisły związek żadnej z cech z przestępczością. Nie można więc na tej podstawie wskazać jednej cechy, która determinowałaby w jakiś sposób przestępczość na danym terytorium, co wskazuje na konieczność stosowania analizy wielowymiarowej.

3. Zastosowana metoda wzorca i antywzorca pozwoliła na stworzenie zmiennej syntetycznej i w efekcie na utworzenie rankingu powiatów ze względu na poziom zjawiska przestępczości. Obliczona miara G, określająca zdolność miernika rozwoju do grupowania badanych powiatów, wyniosła 0,506253 , co świadczyło o dobrej zdolności do podziału powiatów na grupy typologiczne, co mogłoby być wykorzystywane w dalszej analizie $\mathrm{i}$ badaniu.

4. Przeprowadzona ocena zgodności wyników klasyfikacji nie dostarczyła jednoznacznej odpowiedzi, czy klasyfikacja powiatów ze względu na współczynnik przestępczości i ranking powiatów uzyskany z zastosowaniem syntetycznej miary rozwoju są zależne. Zgodnie z tym nie byłoby zasadne wnioskowanie na podstawie współczynnika V-Cramera. Należałoby w tym przypadku zastosować inny podział grup typologicznych lub odnieść syntetyczną miarę rozwoju do podziału powiatów według innego kryterium, co mogłoby poprawić dopasowanie.

5. Określone metodą Warda grupy powiatów w większości przypadków utworzyły jednorodne skupienia, co świadczy o tym, że sąsiadujące z sobą powiaty mają jednorodną strukturę wewnętrzną. Może to oznaczać, że na przestępczość w sąsiadujących z sobą powiatach mogą wpływać takie same lub o podobnym stopniu cechy.

6. Wyznaczony wskaźnik sylwetkowy GSI, który przyjął wartość 0,118 , oznacza, iż nie wykryto struktury w zastosowanym podziale na grupy. Wskazane byłoby zastosowanie innego podziału lub wykorzystanie innej metody hierarchicznego grupowania.

7. Należy podkreślić, że konieczne jest rozwinięcie badań na temat determinantów przestępczości i zaproponowanie innych czynników mogących mieć wpływ na kształtowanie tego zjawiska, co mogłoby poprawić zgodność klasyfi- 
kacji ze współczynnikiem przestępczości. Warto również wspomnieć, że bardziej odpowiednie mogłoby się okazać wykorzystanie innej metody wielowymiarowej i rozszerzenie badań. Temat badania czynników wpływających na zjawisko przestępczości nie został wyczerpany, a analiza mogłaby zostać przeprowadzona z podziałem na czynniki o różnym rodzaju, co mogłoby ją uszczegółowić.

\section{Bibliografia}

Adamowicz, A., Janulewicz, P. (2012). Wykorzystanie metod wielowymiarowych w określeniu pozycji konkurencyjnej gminy na przykładzie województwa lubelskiego. Metody Ilościowe w Badaniach Ekonometrycznych, 18, 1, Państwowa Szkoła Wyższa im. Papieża Jana Pawła II w Białej Podlaskiej. Katedra Ekonomii i Zarządzania. Uniwersytet Przyrodniczy w Lublinie.

Balicki, A. (2009). Statystyczna analiza wielowymiarowa i jej zastosowania społeczno-ekonomiczne. Gdańsk: Wydawnictwo Uniwersytetu Gdańskiego.

Bieniek, P., Cichocki, S, Szczepaniec, M. (2012). Czynniki ekonomiczne a poziom przestępczości. Badanie ekonometryczne. Zeszyty Prawnicze, 12, Uniwersytet Warszawski, Uniwersytet Kardynała Stefana Wyszyńskiego.

Błachut, J. (2007). Problemy związane z pomiarem przestępczości, Warszawa: Wolters Kluwer Polska.

Błażejczyk L. (2018). Zastosowanie analizy skupień w przypadku zmiennych wyrażonych na skali porzadkowej. Data dostępu: 27.12.2019, https://www.statsoft.pl/wp-content/uploads/2018/11/ analiza_skupien_i_zmienne_na_skali_porzadkowej.pdf.

Cheba, K. (2010). Przestrzenne zróżnicowanie wybranych wskaźników poziomu życia mieszkańców miast średniej wielkości a system logistyczny miast. Metody ilościowe w badaniach ekonomicznych, 9, 2.

Czarnecki, B. (2009). Przestrzenne aspekty przestępczości. Metoda identyfikacji czynników zagrożeń w przestrzeni miejskiej. Rozprawy Naukowe, 216. Białystok: Oficyna Wydawnicza Politechniki Białostockiej, 21.

Ellis, L., Beaver, K., Wright, J. (2009). Handbook of Crime Correlates, San Diego: Academic Press.

Grajewski, S. (2006). Zastosowanie analizy skupień w porównawczych badaniach zdolności retencyjnych ekosystemów leśnych. Infrastruktura i Ekologia Terenów Wiejskich, 3, 1. Polska Akademia Nauk. Oddział w Krakowie. Komisja Technicznej Infrastruktury Wsi.

Grzeszyk, C., Sławik, K. (1985). Przestepczość a kryminalistyka. Warszawa: Wydawnictwo Prawnicze.

Gucik, R. (2000). Przestrzenny obraz przestępczości w prasie krakowskiej. Prace Geograficzne, 106, Kraków: Instytut Geografii UJ.

Hołyst, B. (2016). Kryminologia. Warszawa: Wolters Kluwer.

Kądziołka, K. (2015). Bezrobocie, ubóstwo i przestępczość w Polsce. Analiza zależności na poziomie województw. Studia Ekonomiczne. Zeszyty Naukowe Uniwersytetu Ekonomicznego w Katowicach, 242.

Kądziołka, K. (2016). Przestrzenne zróżnicowanie zagrożenia przestępczością. De Securitate et Defensione. O Bezpieczeństwie i Obronności, 2.

Kiersztyn, A. (2008). Czy bieda czyni złodzieja? Zwiąki między bezrobociem, ubóstwem a przestępczościa. Warszawa: Wydawnictwo Uniwersytetu Warszawskiego.

Nowak, E. (1990). Metody taksonomiczne w klasyfikacji obiektów społeczno-gospodarczych. Warszawa: Wydawnictwo PWE.

Panek, T., Zwierzchowski, J. (2013). Statystyczne metody wielowymiarowej analizy porównawczej. Teoria i zastosowania. Warszawa: Oficyna Wydawnicza SGH.

Ekonomia - Wroclaw Economic Review 26/1, 2020

(C) for this edition by CNS 
Park, R.E., Burgess, E.W. (1925). The City Suggestions for Investigation of Human Behavior in the Urban Environment. Chicago: The University of Chicago Press.

Siemaszko, A., Marczewski, M., Gruszczyńska, B. (red.) (2015). Atlas przestępczości w Polsce. Warszawa: Oficyna Naukowa Ewa Pajestka-Kojder.

Sobolewski, M. (2015), Automatyzacja analizy skupień w programie STATISTICA. Humanities and Social Sciences, 20, 22.

Stanisz, A. (2007). Przystępny kurs statystyki z zastosowaniem STATISTICA PL na przyktadach $z$ medycyny. Kraków: StatSoft.

Szczepaniec, M. (2011). Kontrowersje wokół wpływu warunków ekonomicznych na poziom przestępczości, Czasopismo Prawa Karnego i Nauk Penalnych, 4.

Szkutnik, W., Hadaś-Dyduch, M., Sączewska-Piotrowska, A. (2015). Metody taksonomiczne z programem STATISTICA. Katowice: Wydawnictwo Uniwersytetu Ekonomicznego w Katowicach.

Sztaudynger, J., Sztaudynger, M. (2004). Ekonometryczne modele przestępczości. Zeszyty Naukowe Uniwersytetu Szczecińskiego, 394. Prace katedry ekonometrii i statystyki, 15.

Walesiak, M. (1990). Ocena zgodności wyników klasyfikacji w świetle postulowanych właściwości. Prace Naukowe Akademii Ekonomicznej we Wrocławiu, 524.

Wałęga, A., Krzanowski, S., Chmielowski, K. (2009). Wykorzystanie metody analizy skupień do identyfikacji jednorodnych zlewni pod względem indeksów powodziowości i wybranych charakterystyk fizjograficznych. Infrastruktura i Ekologia Terenów Wiejskich, 6.

Wasilewska, E. (2011). Statystyka opisowa od podstaw. Podręcznik z zadaniami. Warszawa: Wydawnictwo Szkoły Głównej Gospodarstwa Wiejskiego.

Ekonomia - Wroclaw Economic Review 26/1, 2020

(C) for this edition by CNS 